\section{5. 考，察}

前述の精製法によるKRP をビスコース化し 紡系しを場合，ビスコース粘度は普通の SRP に比較し䯩ん故アルカリセルローズの老成溫度 を高めるかして調整する必琶がある樣だ。パル プの重合沾はもつと低くともビスコースとして

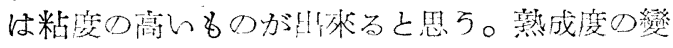
化, 粘度戀化等\& SRP と何等傾问安異にLて

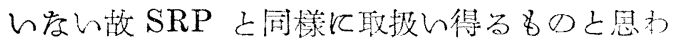

・れる。溜渦の點でもモドセル上り䒴干劣名沾果 岁出ているので交障存い楾存パルプを作り得 るもの之思われる。紡系しを系の性質为何等

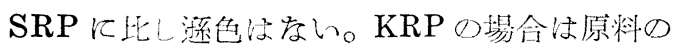

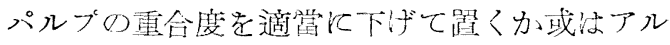
カリセルローズの老成の際ビスコース粘度の調 整を行わ奴代存らない點が SRP 上湋つている。

\section{總}

括

クラフト法による人綃用パルプの製造研究を 赤松材について行い, 從來侀究並儿土業化され ているチップの前斿水分解處理の才法飞依ら ず，アルカリ蒸解老行つて待を未酒クラフトパ ルプの精製漂白處理工程中に酸處理の一工程を 加えることにより簡算に浴解性能のよん人絹用 パルプを得を。粗製に用いる未瞄パルプはスク リーンにて節斯しを精撰 パルプの收率， $\alpha$ ーセ ルローズの收率或は緎維素の萠壞の程度等を考 虑して蒸解度としては $\mathrm{O}^{\circ} \mathrm{C}$ 亿於的方監素吸收 率として5\%前後のものを用ふる事が最もよん 事を知つ它。

酸處理のお法は第 1 段で鹽素處理しを庫液中

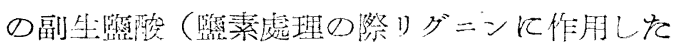
監素のて0\%に相當する監酸が生ず）を艺のま〉

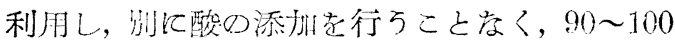
で 1 時間處理することにより婹處理を行うるの で，并の後は通常の方法の如く、アルカリ處 理，八イポクロライト處理等に上り容易に，

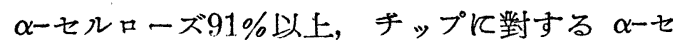
ルローズ收率約 $34 \%$ で，ビスコース化した際の 㴓通性も良い精製パルプが得られる。 一ズ会量の间上や製品の色相の向上を許名場合

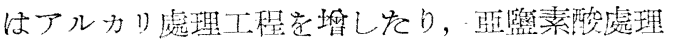

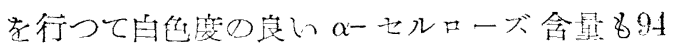

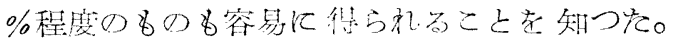

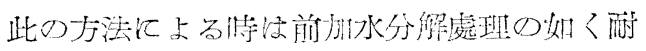

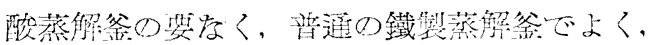

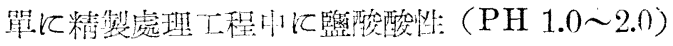
で約 $100^{\circ} \mathrm{C}$ 亿附える管理設借をするのみでよく，

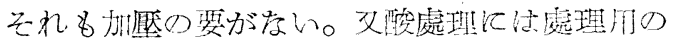
酸上して新しい酸を用万る必要のをん管の利點 がある。

ビスコース試驗の結果から見でルファィト 法のパルプと比較してビスコースの㤬䝷は何等

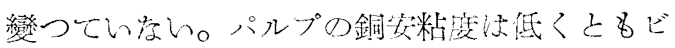
スコース化しを坋合のビスコ一ス粘喼が高い故

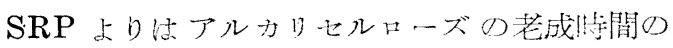

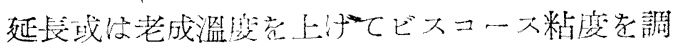
整する要がある。

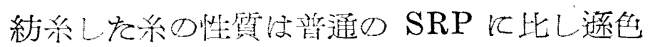
はない㮛だ。此方法によるパルプの精製法はク ラフト法による人絹用林朴パルプ㹈造法の名程

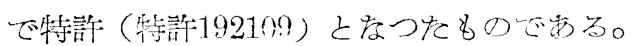

附 记

（1）濶葉樹については斺飞常盤，本閐，山路

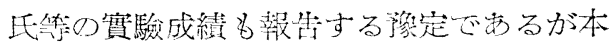

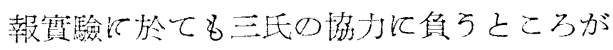
多的。

(2) ビスコース紡系實驗について特於りの御配 虑安らけを瀻維工業試驗所の前田弘邦，渵

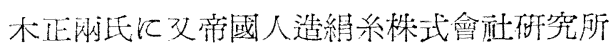

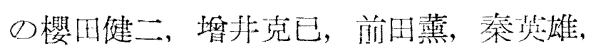
宿田正之之の諸氏代感謝与る。 （筆者・國策パルプエ業・農林化學砄究所）

\title{
亞硫县パルプ廢液え原料とする酒精製造に就て
}

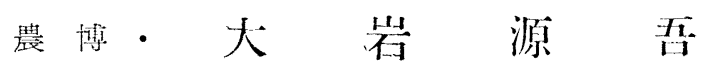

今回パルプ及紙挍術協會から亞硫酸パルプ廃 液を原料とする酒精製造に就て㫪く㧺に々つ御

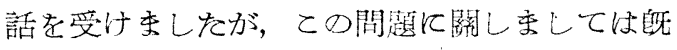

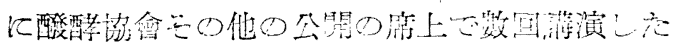


事もありますし，企業として筫際に操業してか ら十五年以上にも右る問題で蚂りますので，既

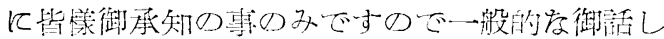

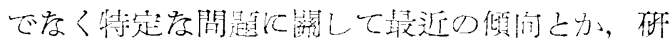

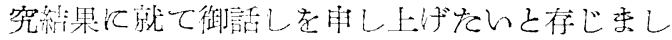

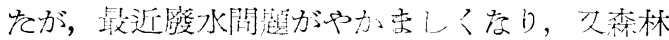

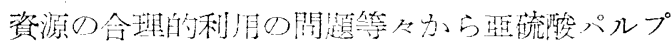

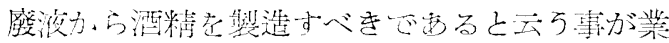

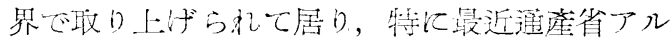

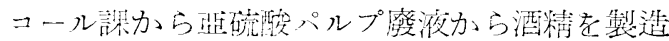

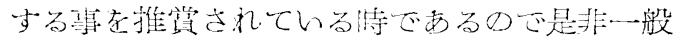

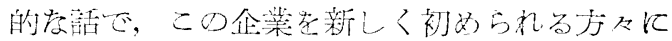

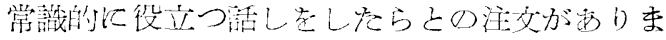

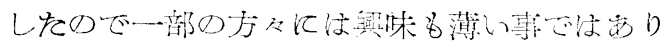
まし上うが，存るべく最近の倾问，哳究結果孝

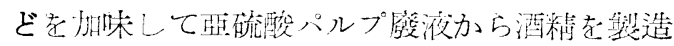

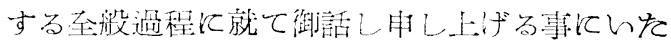

\section{しをんと存じます。}

\section{1. どんな種類の廢液が酒精製造に適するか}

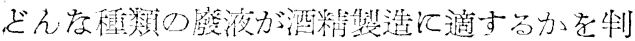

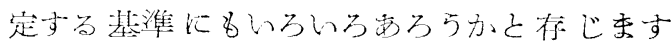

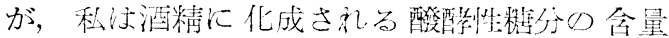

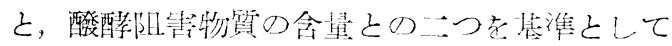
御話し々たします。

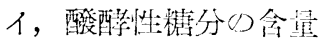

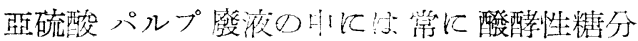

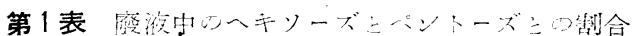

\begin{tabular}{|c|c|c|c|c|}
\hline \multicolumn{2}{|c|}{ 原料柲心租数 } & \multirow{2}{*}{ 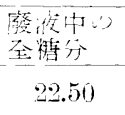 } & \multicolumn{2}{|c|}{ 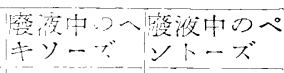 } \\
\hline 白菲惟 & No. 1 & & 9.90 & 19.60 \\
\hline 白檴材 & No. 2 & 21.75 & 9.81 & 12.44 \\
\hline 少什 & No. 1 & 36.13 & 15.15 & 20.98 \\
\hline プナ秒 & No. 2 & 37.06 & 16.26 & 21.80 \\
\hline 葦 & No. 1 & 9.30 & 1.60 & 7.70 \\
\hline 戴: & No. 2 & 9.10 & 1.30 & 7.60 \\
\hline 材 & No. 1 & 30.63 & 28.01 & 2.62 \\
\hline 䧻 秋 & No. $:-$ & 35.78 & 32.67 & 3.11 \\
\hline 白秴材 & No, 1 & 30.20 & 28.04 & 2.16 \\
\hline 白榆材 & No, 2 & 32.27 & 29.90 & 2.37 \\
\hline ・バ䊝材 & No. 1 & 26.62 & 19.37 & 7.25 \\
\hline トド松材 & No. 2 & 26.20 & 19.05 & 7.14 \\
\hline エゾ松材 & No. 1 & 26.20 & 19.05 & 7.14 \\
\hline エゾ松财 & No. 2 & 25.01 & 18.94 & 6.06 \\
\hline 落葉松材 & No. 1 & 54.20 & 49.04 & 5.16 \\
\hline 落葉松材 & No. 2 & 59.40 & 42.40 & 17.00 \\
\hline 苏松 & No. 1 & 45.00 & 4.89 & 2.61 \\
\hline 赤 & No. 2 & 51.16 . & 37.11 & 14.05 \\
\hline
\end{tabular}

(ヘキソーズ) と非醊酵性糖分 (ペントーズ) と が其存していますが，之の制含は必柇も一定。 て蛙りません。一例として次に私の分析した 結森を示しなす。

この袁で御覽の通门同一原料朴を使用しても

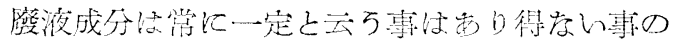

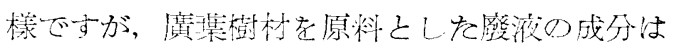

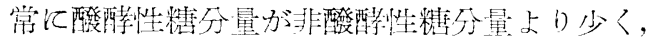

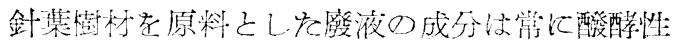

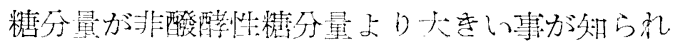

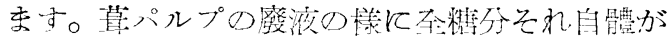

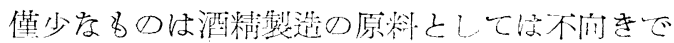
ありますが，奆粯の含量が大をくても廣集樹の

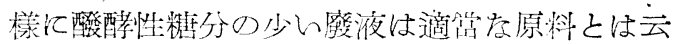

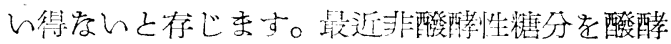

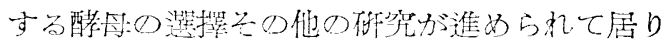

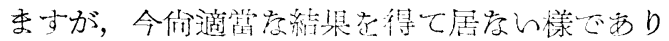
委す。

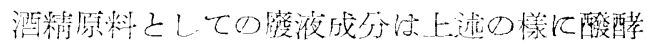

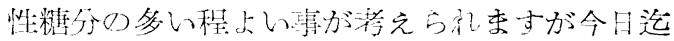

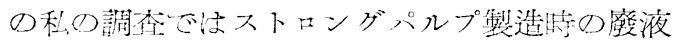
よりイージィパルプ製造特の激液の方が症分含

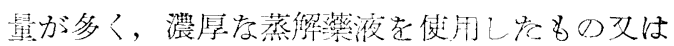
液比の少い子のは一般に糖分含量が多く，低溫

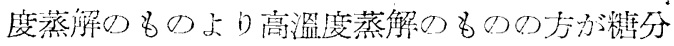
会量が多く，北方材を原料としたもの上り献方 材を原料としをもの〉方が糆分含量が多い樣に 考えられ李す。

口，醴酵阻害物質の含量

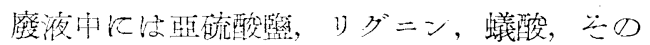

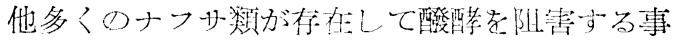
は古く方放知录ている處な゙あり委。今一例

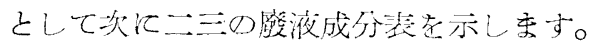

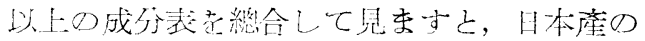

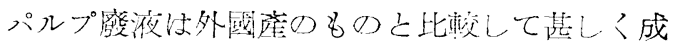

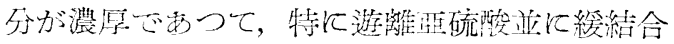
堅硫酷が少々，永久結合の开硫酸が多ん事が認

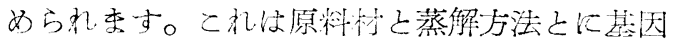
すえものと洘え委すが，りグニン分解物その他

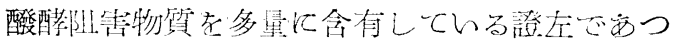

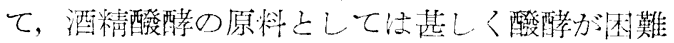
なパルプ噔液であることが容易に理解出來方所 であります。

パルプ廢液は桾分含量が他の酒精原料之比輍

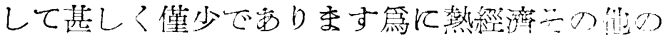


第 2 表 亞硫酸バルプ庣菹の一般成分

\begin{tabular}{|c|c|c|c|c|c|c|}
\hline \multirow{2}{*}{ 試 } & \multirow{2}{*}{\multicolumn{2}{|c|}{4}} & \multicolumn{2}{|c|}{ 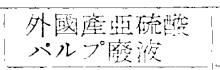 } & \multicolumn{2}{|c|}{ 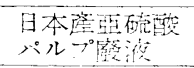 } \\
\hline & & & No. 1 & No. 2 & No. 1 & No. 2 \\
\hline 全国 & 形 & 分! & 118.00 & 114.80 & 181.87 & 176.26 \\
\hline 灰 & & 分 & 19.01 & 16.85 & 20.45 & 18.96 \\
\hline 条 挥 & 唂 & 限 । & 5.31 & 4.98 & 6.18 & 7.57 \\
\hline 蟻 & & 睖! & 0.63 & 0.65 & 1.14 & 0.49 \\
\hline 醋 & & 陵 & 4. & -0 & & .08 \\
\hline 石 & & 㤦 & 7.24 & 47 & 0 & $\therefore t$ \\
\hline 全 & & 黄 & 10.29 & 10.83 & $11.8 \pm$ & $13.6^{\circ}$ \\
\hline 硫 & & 鼠 & 2.24 & 1.73 & .64 & 6.96 \\
\hline 遊離 垚 & 硫 & 部 & 1.89 & 8.43 & 0.27 & 11.2 .2 \\
\hline 緮給㑒 & 譬䂶 & 8 & 4 & 50 & & 4.28 \\
\hline 永久待全 & 亞硫 & 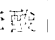 & 12.41 & 11.37 & 51 & 15.93 \\
\hline 有 & & 4 物 & 110.00 & 104.40 & 160.00 & 157.49 \\
\hline$x \neq r \cdot r$, & $2 \cdot 2$ & & 1.26 & 1.01 & 2.20 & 0.32 \\
\hline エ千几ケ? & $2=$ & $\pi$ & 0.17 & 0.16 & 0.42 & 0.44 \\
\hline$\Rightarrow \pi$ & $9-$ & $n$ & $0 . .8$ & 0.28 & .56 & 0.96 \\
\hline$ク ゙$ & $=$ & $\because$ & $61.50^{\prime}$ & 60.20 & 84.83 & 85.36 \\
\hline 七 & $\therefore$ & $y$ & 0.13 & 0.15 & 1.09 & 0.27 \\
\hline 埾 & & 分 & 20.15 & $20.10^{\circ}$ & 45,00 & 51.16 \\
\hline 人⿻y & - & ズ & $17.69^{\prime}$ & 17.50 & $4: .39$ & 37.11 \\
\hline ヘํ. & - & ズ! & $9.5 \%$ & 2.60 & 5.61 & 14.05 \\
\hline
\end{tabular}

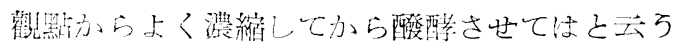

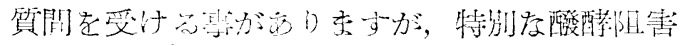

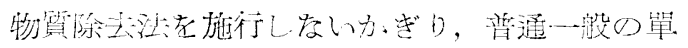

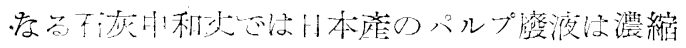

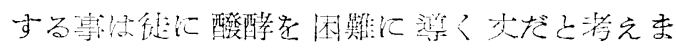

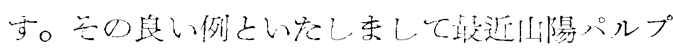

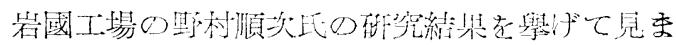

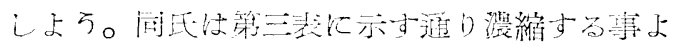

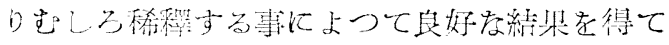
い号のだ勒り亲す。

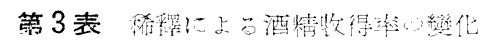

\begin{tabular}{|c|c|c|c|c|}
\hline 符 & 釋＼cjkstart参 & $1000 \%$ & $50 \%$ & $0 \%$ \\
\hline 醴 & $\mathrm{PH}$ & 5.4 & 5.4 & 5.4 \\
\hline 酔 & 比 望 $\left(15^{\circ} \mathrm{C}\right)$ & 1.051 & 1.074 & 1,083 \\
\hline 前 & 爻 糖 分 品 & 2.05 & 8.075 & 4,19 \\
\hline 惧發 & 酵 時 間 & 72 & 72 & 72 \\
\hline 酸 & PH & $\therefore .2$ & 5.2 & 5.1 \\
\hline 酵 & 殘 籶 分 首 & 0.8 & 1.07 & 1.77 \\
\hline 後 & 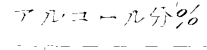 & 0.9 & 1.1 & 1.95 \\
\hline & 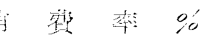 & 60.5 & 65.02 & 56.9 \\
\hline 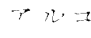 & 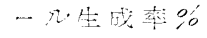 & 68.7 & 56.0 & 51.5 \\
\hline
\end{tabular}

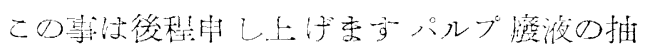

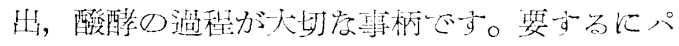

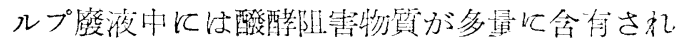

て居りますので, '單に醱酵性糖分量丈ではその

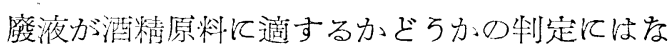
ら存い事安申し上げをんのであり亦す。

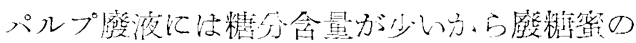

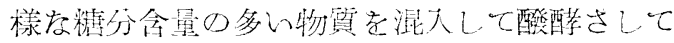

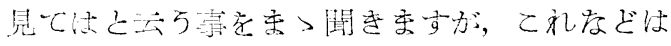

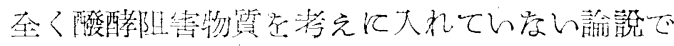

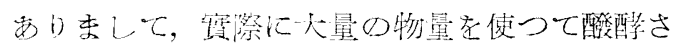

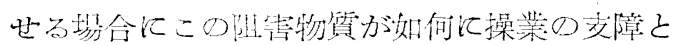

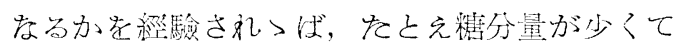

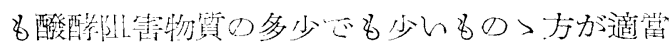

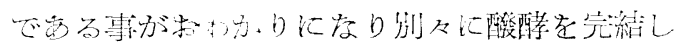

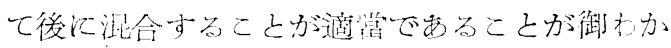
门江疗る之标心委す。

\section{2. 木金加ら醱酵槽迄}

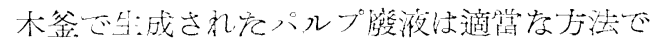

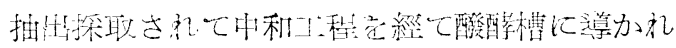

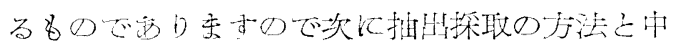
和厂程とに就て早し上げて题をいと标じすす。

\section{イ，パプ糜液の抽出採取方法}

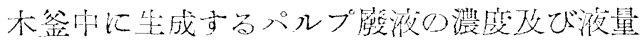

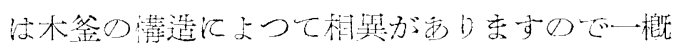

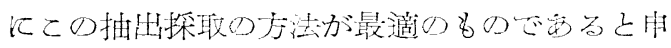

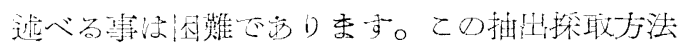

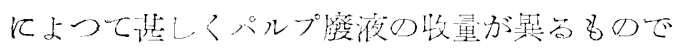
めりますので徒つてパルプ顿當りの酒精收得量

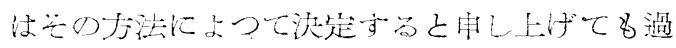

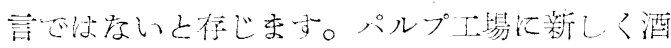

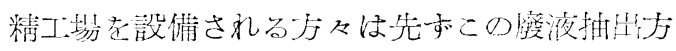

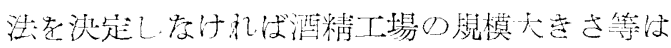

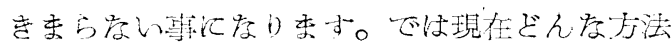

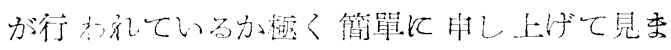
声。

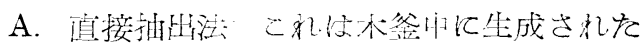

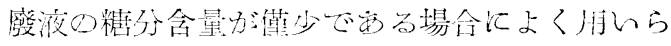

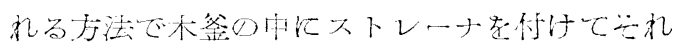

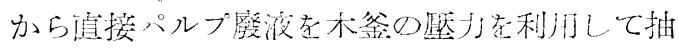

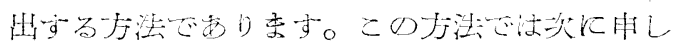

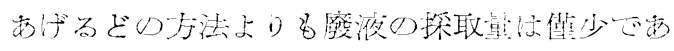

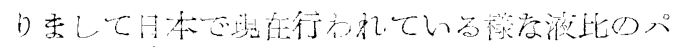

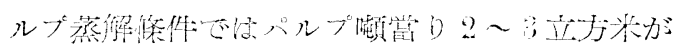

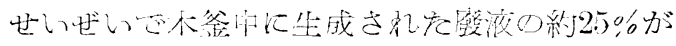

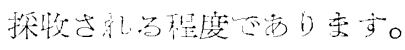

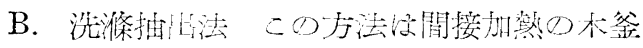

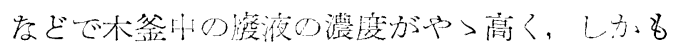


液比の低々場合飞用いられる方法で先に申しあ

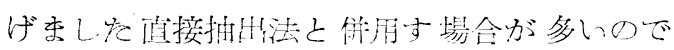
す。初めパルプビンに排壮され花噔液の队で洗

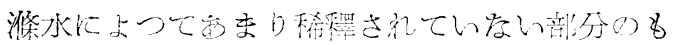

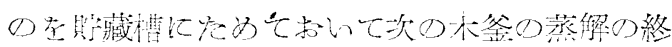

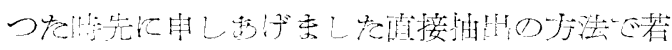

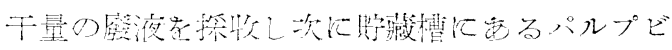

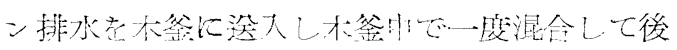

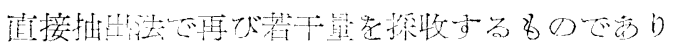

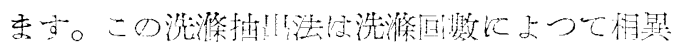

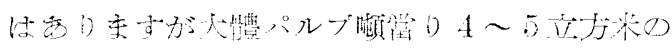

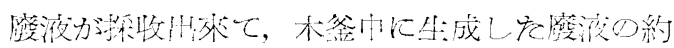

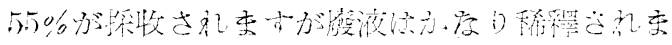
于。

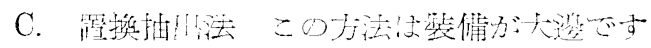

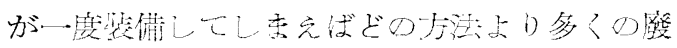

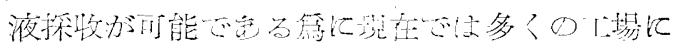

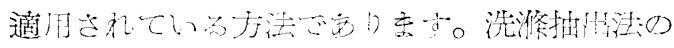

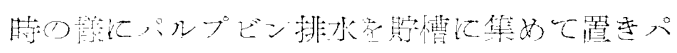

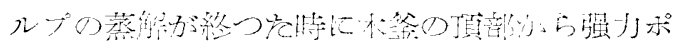

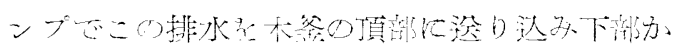

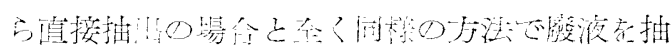

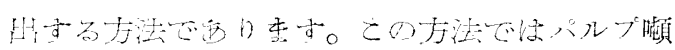

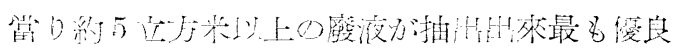

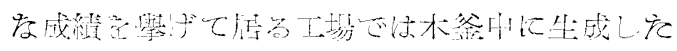

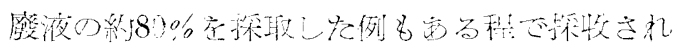

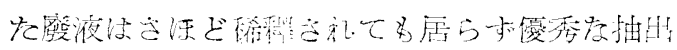

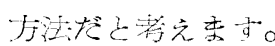

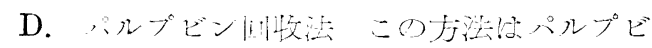

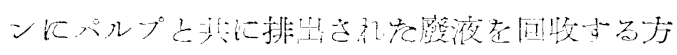

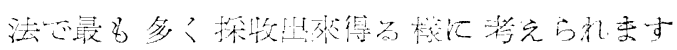

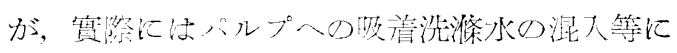

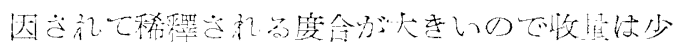

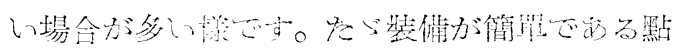

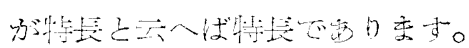

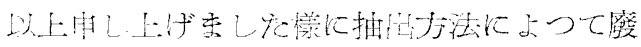

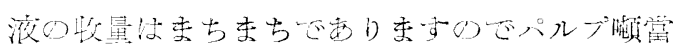

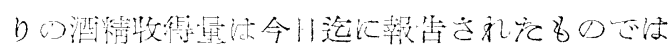
30 立了.

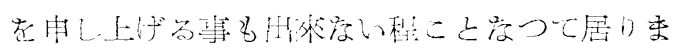

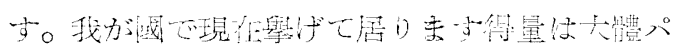

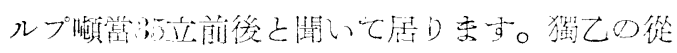

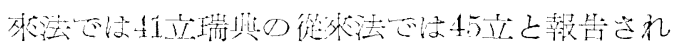

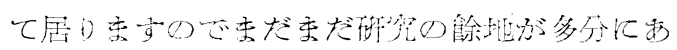

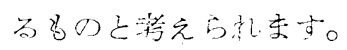

\section{3. パルプ廢液の中和工程}

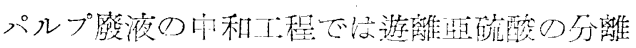

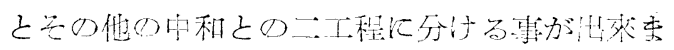

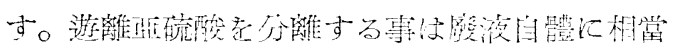

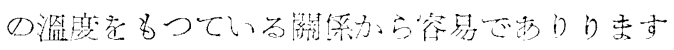

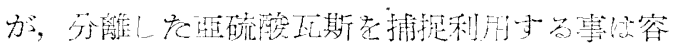

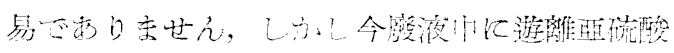
を $\mathrm{SO}_{2}$ とて $0184 \%$ 自含んでいる場合老例にと

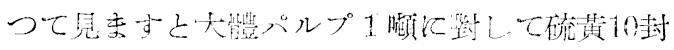

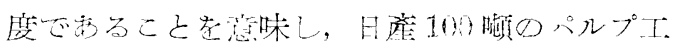

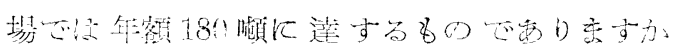

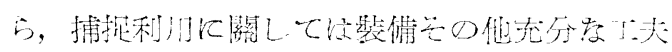

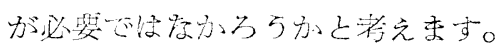

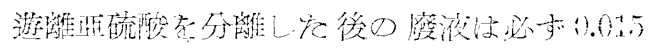

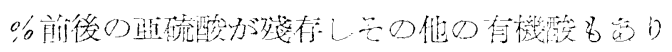

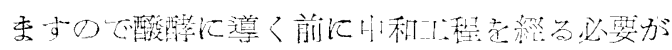

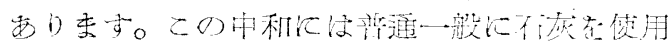

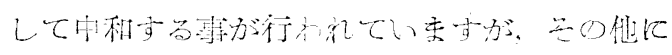

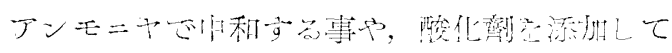

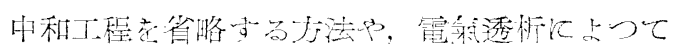

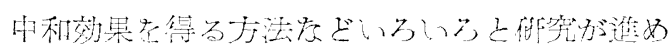

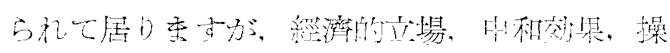

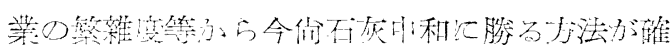

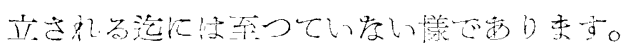

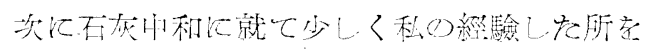

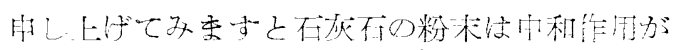

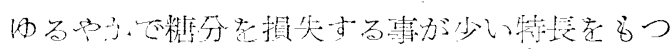

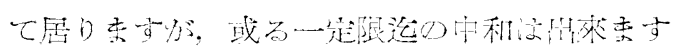

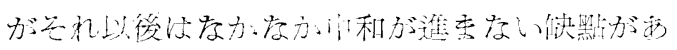

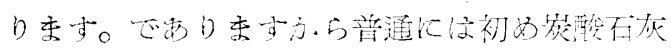

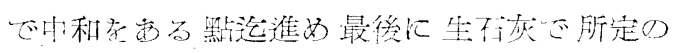

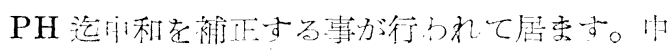

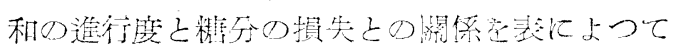

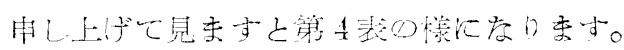

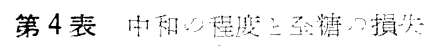

\begin{tabular}{|c|c|c|c|}
\hline 中和微のPH & 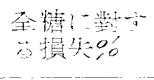 & 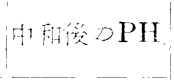 & 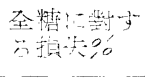 \\
\hline 4.5 & 0.1 & 6.9 & 11.8 \\
\hline 5.0 & 0.2 & 0.5 & 3.0 \\
\hline 5.5 & 0.4 & 7.0 & 10.2 \\
\hline
\end{tabular}

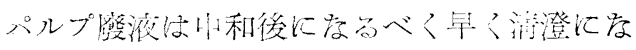

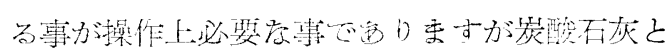

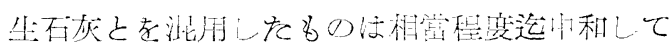

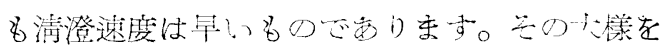


表で說明々たしますと第5表の通りでありま す。

第 5 表 中和乞濁废上の關係

\begin{tabular}{|c|c|c|c|c|c|}
\hline $\begin{array}{l}\text { 實 踩 } \\
\text { 番號 }\end{array}$ & 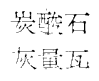 & $\begin{array}{l}\text { 生石灰 } \\
\text { 量 瓦 }\end{array}$ & $\begin{array}{l}\text { 中和後 } \\
\mathrm{PH}\end{array}$ & 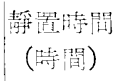 & 攞 鹿 \\
\hline 1 & 0.6 & 0.1 & 5.6 & 2 & 400 \\
\hline 2 & 0.4 & 0.2 & 6.2 & 2 & 3,000 \\
\hline 3 & - & 0.1 & 3.2 & 12 & 1,600 \\
\hline 4 & - & 0.2 & 5.0 & 12 & 3,000 \\
\hline 5 & - & 0.3 & 6.4 & 12 & 3,000 \\
\hline
\end{tabular}

で洁次に普通パルプ簨液の中和汇如何程の不

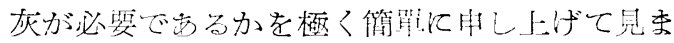
すと第6 美の通りで融ります。

第6表 中和に翼する石荻量

\begin{tabular}{|c|c|c|c|c|c|}
\hline $\begin{array}{l}\text { 筫 驗 } \\
\text { 番 战 }\end{array}$ & 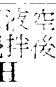 & 宗液。 & $\begin{array}{l}\text { PH4.6 } \\
\text { 中和 } \\
\text { 粉石 }\end{array}$ & 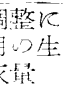 & $\begin{array}{l}\text { 整㷋 } \\
\mathrm{H}\end{array}$ \\
\hline 1 & 2.2 & $\begin{array}{c}\text { Grt米 } \\
100\end{array}$ & 525 & $\begin{array}{l}185 \\
188\end{array}$ & 5.7 \\
\hline 2 & $\stackrel{2.4}{4}$ & 100 & 525 & 225 & 5.8 \\
\hline 3 & 2.4 & 100 & 525 & 188 & 5.6 \\
\hline 4 & 2.2 & 100 & 525 & 188 & 5.4 \\
\hline 5 & 2.4 & 100 & 525 & 225 & 5.8 \\
\hline 6 & 2.2 & 100 & 525 & 262 & 5.8 \\
\hline 7 & 2.2 & 100 & 525 & 225 & 5.8 \\
\hline 平均 & 2.3 & 100 & 525 & 214 & 5.7 \\
\hline
\end{tabular}

以上申し上げました通り炭陵不灰と生石灰と を混用して所和する事が普通一般行行礼て居 りますが、では中和はどの程度迄中和したらよ

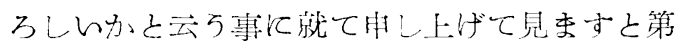
7 至の示吉通口不灰山和の P.H は酵母最適 P. $\mathrm{H}$ 上り多少低く中和度は 5.0 前後の榚であり ます。勿論策緟源々の他を添加して一度中和し た後にP.H の上竍する事为将えられますが， その場含でも中和の基準が 5.0 前後であれ壮最

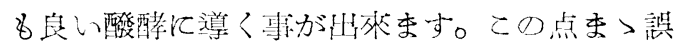
解される事がありますので特に申し上げます。 佮 PH 3.5以下の中和では極端に酸酵率が低下 し，6.0以上になりますと糖分り損失が懸念さ

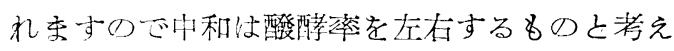

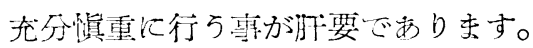

第 7 表 中和度と醱醭率との關係

\begin{tabular}{|c|c|c|c|}
\hline $\begin{array}{l}\text { 水素イオ } \\
\text { ソ濃度 }\end{array}$ & $\begin{array}{l}24 \text { 時間目の } \\
\text { 残糖分 }(\%)\end{array}$ & $\begin{array}{l}48 \text { 時間目の } \\
\text { 残精分 (\%) }\end{array}$ & $\begin{array}{l}72 \text { 時間目の } \\
\text { 殘粕分 }(\%)\end{array}$ \\
\hline 3.2 & 4.26 & 3.98 & 3.67 \\
\hline 3.5 & 3.30 & 2.46 & 1.96 \\
\hline 4.1 & 3.20 & 2.07 & 1.67 \\
\hline 4.6 & 3.58 & 1.11 & 1.18 \\
\hline 5.0 & 3.37 & 1.18 & 0.94 \\
\hline 5.6 & 3.45 & 1.20 & 1.00 \\
\hline 6.0 & 3.61 & 1.46 & 1.27 \\
\hline
\end{tabular}

\section{4. パルプ廢液の醱酵}

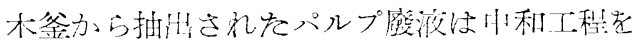

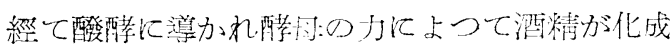
されるものでありますが，光に辿べました通り

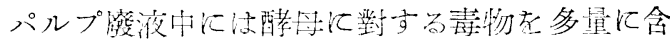

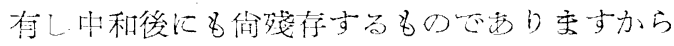

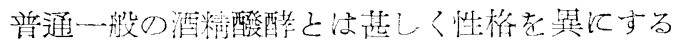

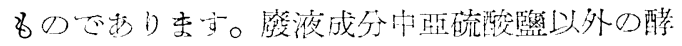

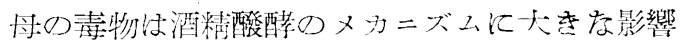

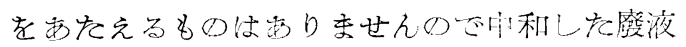

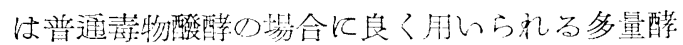

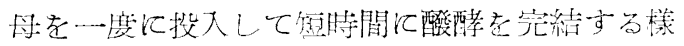

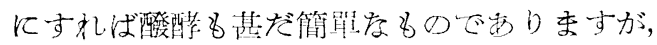

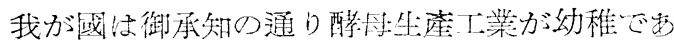

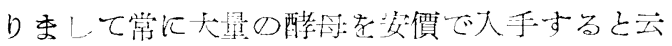

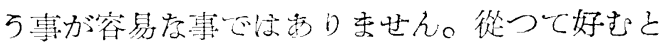

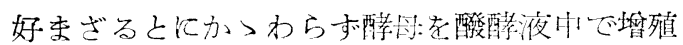

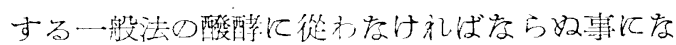

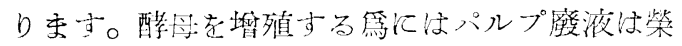

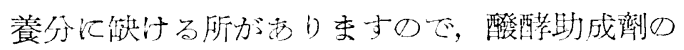
添加が必要に゙あり吉。装求される助成劑の種 類は公素源とビタミン源とであります。乞の添

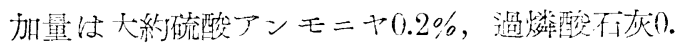
$02 \%$ 米糠 $0.01 \%$ 程度で足るもの之思小れます。

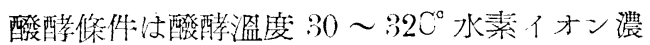

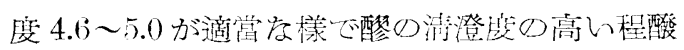
酵が良好を禁ですり古。以上申し上げました

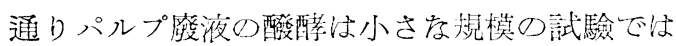

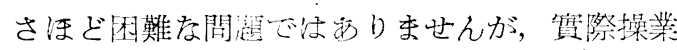
の場合多量の液を使用して酸酵させる侍には毒 物醱䣼であるのと，B.O.D.價の少い事，及び糖

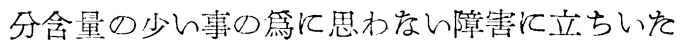


る事があります。毒物瞪酵では特定の酵母の選 定之特定疗仕込方法が要求されますし B. O.D 價に閚してはェアレーションの必要が起りま す。糖分含量の少h高恃特定の仕达方法が要求 され吉。

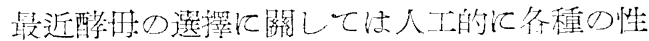

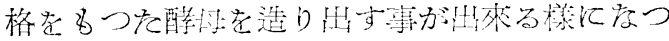

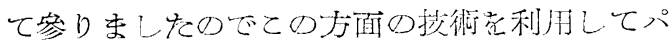

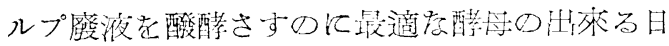

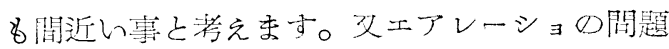
も現行のエアレーションタワーシステムだ充分

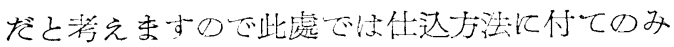
極簡算に中し上げて見をんと存じます。

現在洘えられ安什达方法と致しましては，

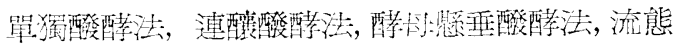

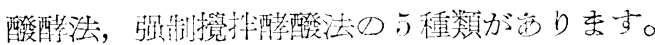

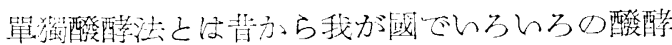
に肺いられている俚达方法でありまして仕达骂 位ごとに一本の槽に仕达む方法であります。連

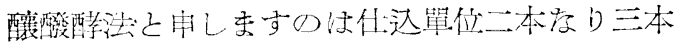

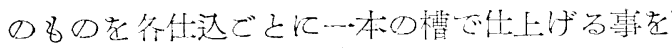

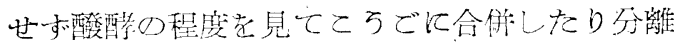

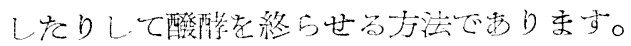

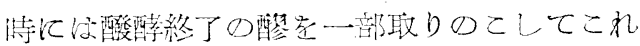

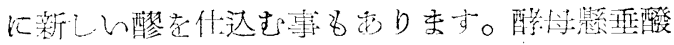

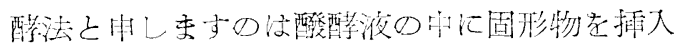

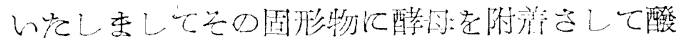

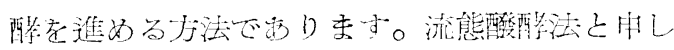

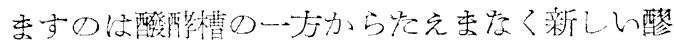

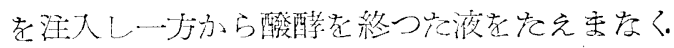

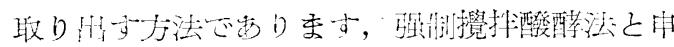

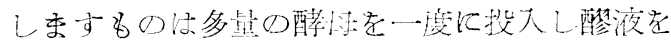

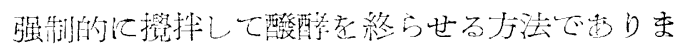

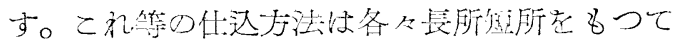

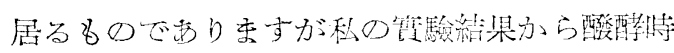

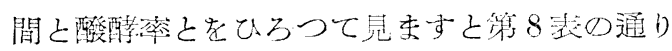
で毒ります。

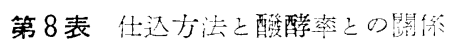

\begin{tabular}{|c|c|c|c|}
\hline 仕泛方法 & 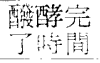 & 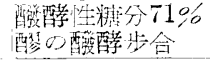 & 酩酸酵卒今 \\
\hline 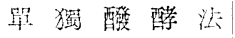 & 70 & $59.5 \%$ & $-83.8 \%$ \\
\hline 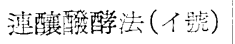 & 55 & $67.11 \%$ & $94.3 \%$ \\
\hline 連㘔酸酵法 ( & 49 & $69.4 \%$ & $97.7 \%$ \\
\hline 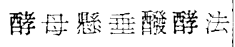 & 28 & $67.5 \%$ & $95.0 \%$ \\
\hline 流 態 醭 酵 法 & 8 & $69.7 \%$ & $98.1 \%$ \\
\hline 强制鄮汼酸醭法 & 4 & $69.5 \%$ & $97.8 \%$ \\
\hline
\end{tabular}

上表では連䤈法と流態法と攪挥法とがすぐれ て居りますが攪拌法は酵母を多量注準備する事 が必要ですが先に申し上げました通り我が國で

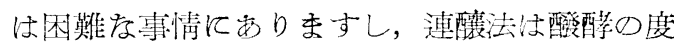

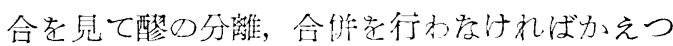

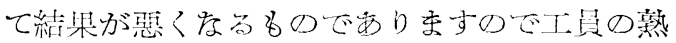
練度老强人要求されますの心概化御す〉め出 來なんと存心゙市。

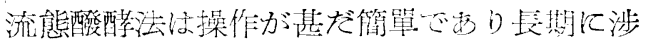
つてトラブルの少ん方法で影り李すので少數の 工員で操業出來る特髟があつてまづまづ推獎し ても艮いお法と洘えて居ります。

\section{5. 酒精の精製}

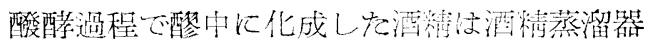

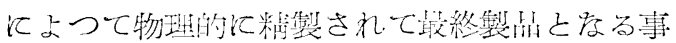

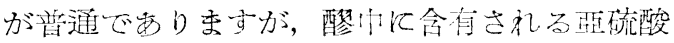
箵，テレビン及び令の分解物关の他他の酒精原

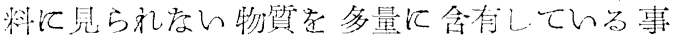

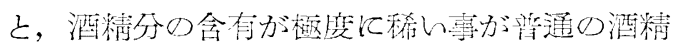

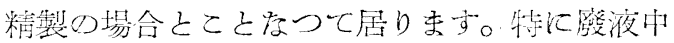
に存佂与タメチルルコール, アルデヒード，

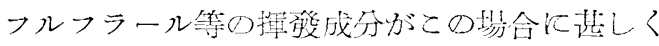
障量と存り末す。

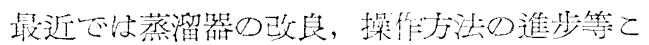

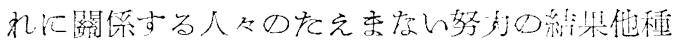

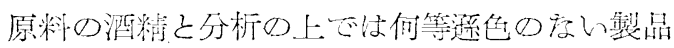

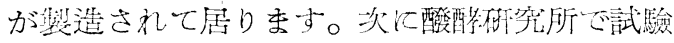

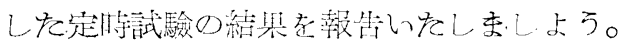

第 9 表 酒精㢣品分析责

\begin{tabular}{|c|c|c|c|c|}
\hline 项 & 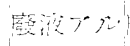 & 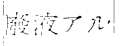 & 甘諸と & 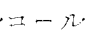 \\
\hline 垻 & $=-N \mathrm{~A}$ & $|\because-n B|$ & No. 1 & No. : \\
\hline 色 & 奥:任透明 & " & 與色透明 & "l \\
\hline 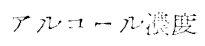 & 96.1 & 94.8 & 95.4 & 95.0 \\
\hline 蒸紧 㸚 直 & 2.0 & 8.9 & 8.0 & 14.0 \\
\hline 酸 & 0.48 & $0 .+1$ & 0) & 0.08 \\
\hline $\begin{array}{l}\text { アセトナルデセ } \\
\text { ード }\end{array}$ & $0 \cdot 78$ & 0.686 & 0.18 & 4.40 \\
\hline $\begin{array}{l}\text { メルケル: } \\
\text { n }\end{array}$ & ナシ & 0.24 & 0 & 0.25 \\
\hline フーゼル油 & $ナ シ$ & 0.0038 & 0.007 & $0.0^{\circ}$ \\
\hline 銅间 & ホシ & $"$ & "1 & "1 \\
\hline$y \square-r$ & ナシ & "l & $"$ & "l \\
\hline カメレオン反應 & $\zeta$ & 20 分 30 秒？ & 50 分 & 19 分 \\
\hline 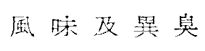 & $\Lambda$ & A & A & A \\
\hline
\end{tabular}


上玟の樣に分析上で估他の酒精と何等遜色が 見られ索ん䍃によく飲料江存りますか上云万事

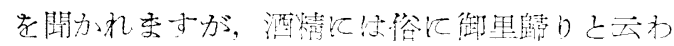

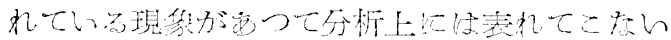

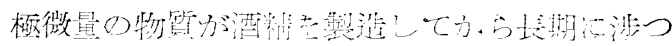

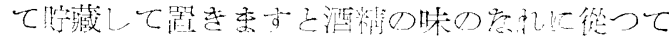

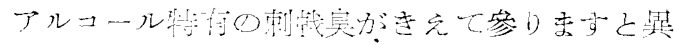

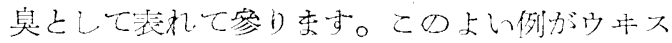

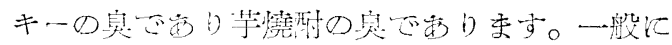

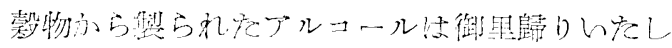

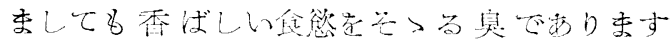

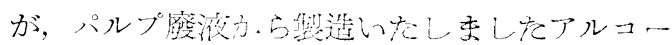

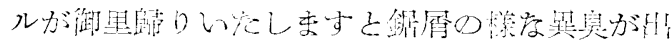

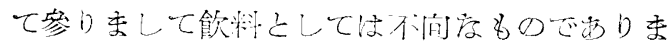

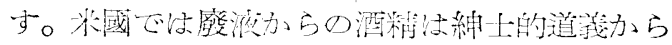

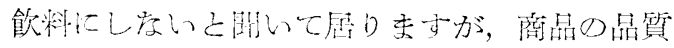

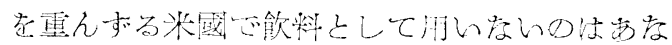

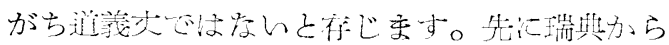

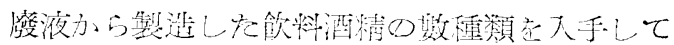

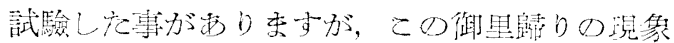

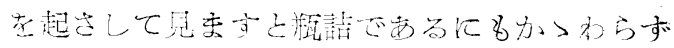

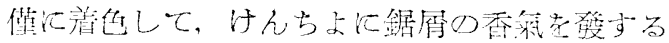

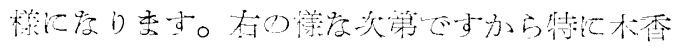

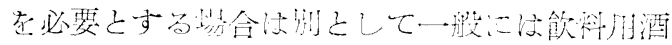

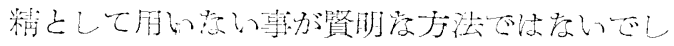
ようか。

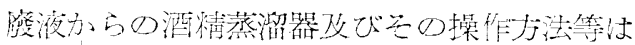
省略い倇しますが最近の調禾によりますと简

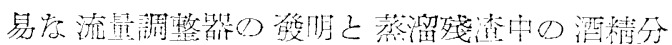

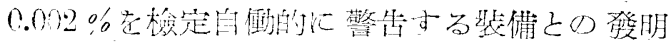

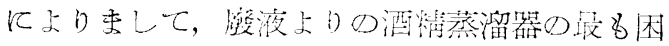
難之寸る微量挎雜物の分離や，微星酒精Q流先

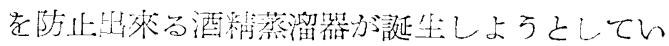

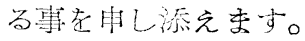

\section{6. 酒精需要供給の現況}

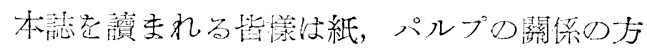
々がその大部分である箖化存ぜられますのだ最

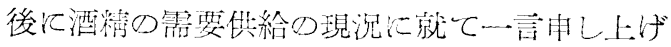
ま守。

我が或で昭和2う年度に製造されましも酒紹の

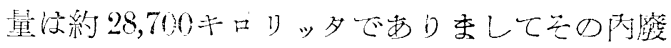
液上りの酒精仕約 $8.5 \%$ ○ 2,422干口りッ夕前後

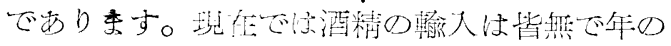
消费量壮從つて $28.000 \mathrm{kl}$ を上下している榚であ す。戰特中の䀡和19年の $167.500 \mathrm{kl}$ 飞比較いた
しますと全く隔世の感があります。可渝戰時中

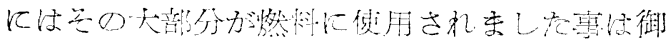

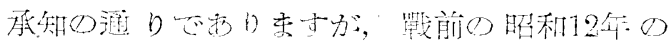

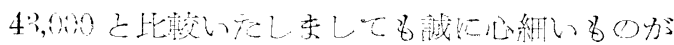
亦门古。

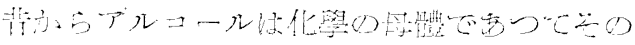

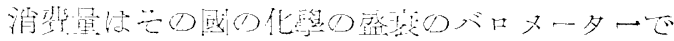

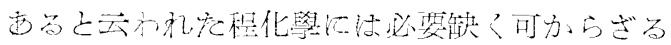

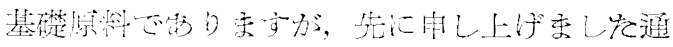

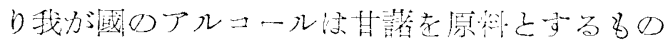

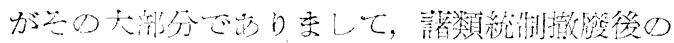
H墸の值上りはアルコールの價犁をつり、レげ生

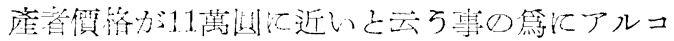

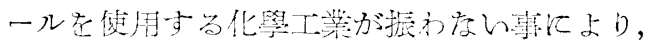

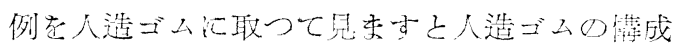

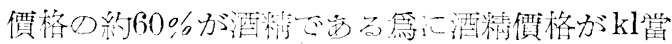

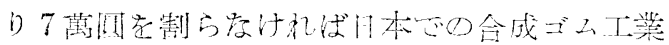

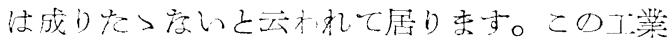

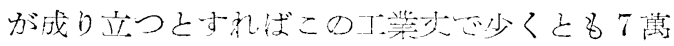

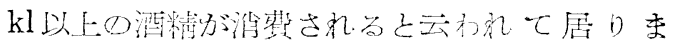
to

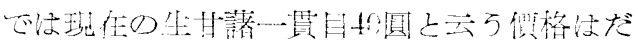

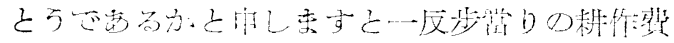

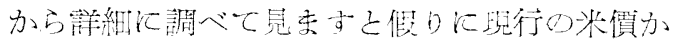

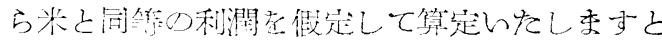

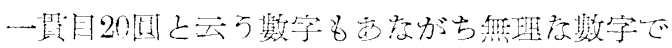

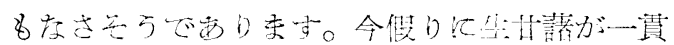

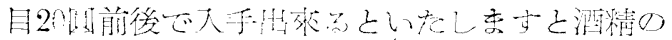

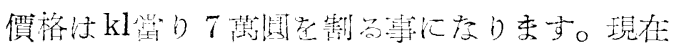

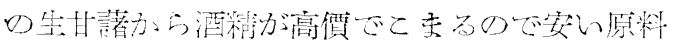

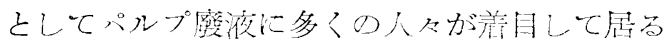

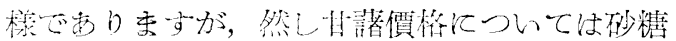

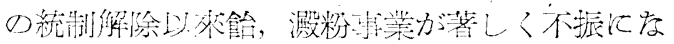

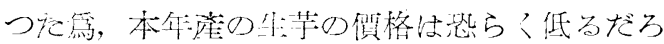
うとの日唀しが强々，この點パルプアルコール

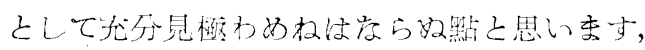

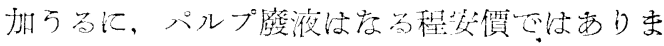

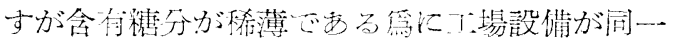

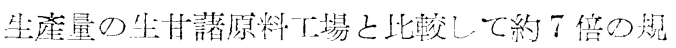

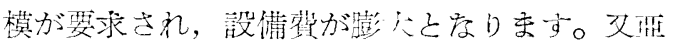

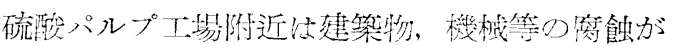
多い之云われて居りますし，隹れに中和丁程は あるにしても亞硫酸監を多量に含んだ液を大量

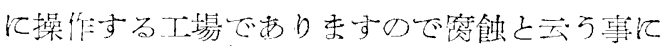
對しては辕溜意する必要がありますので設借 
費がに゙らしても膨大汇度ります。

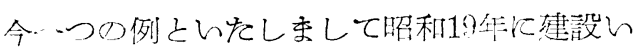

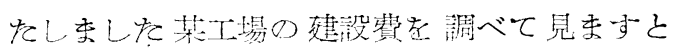

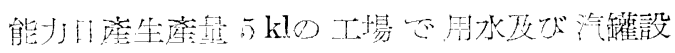

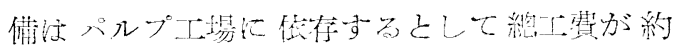

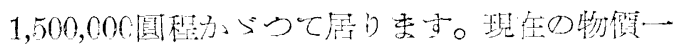

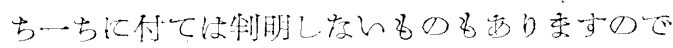

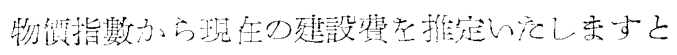

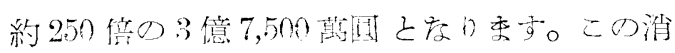

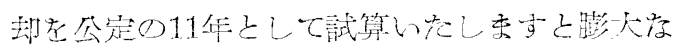

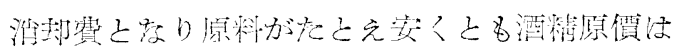

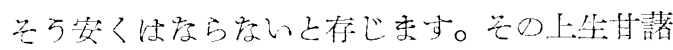

を原料とする酒精製造能力 $80,000 \mathrm{kl}$ を越える 我が國の現存設備能力考考えせを場命に恃，

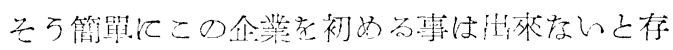
じす。

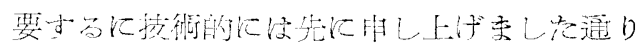

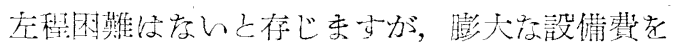
掛けてこの企業を初汤てから星甘榙の暴落が生

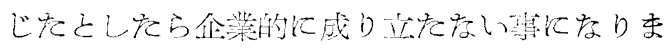

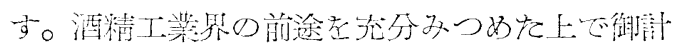

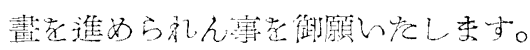

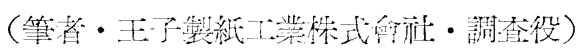

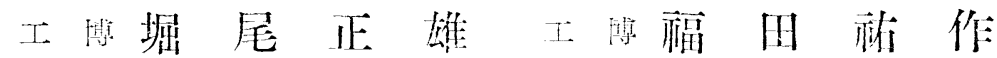

\section{緒}

\section{言}

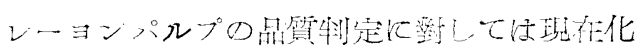

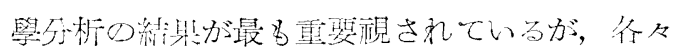
の項目の數字上レーヨンパルプの筫用上の顀值

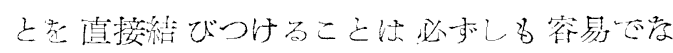

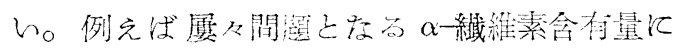
就てみても，关の值の大きいことは好委しいに

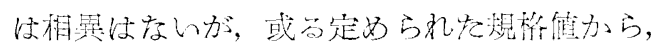
ごく僅か暞買しても, ヴィスョース製遥工程の

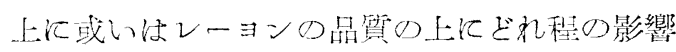

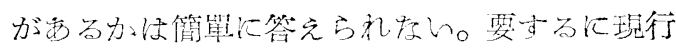

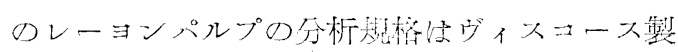

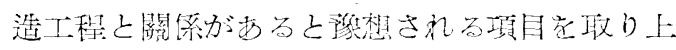

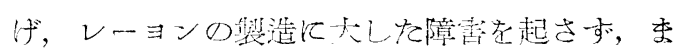
たレーヨンの奛筫在或一定の水愺保保つ上江必

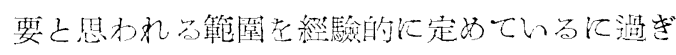

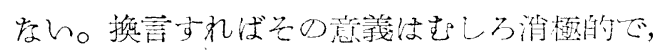

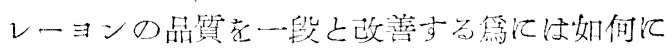

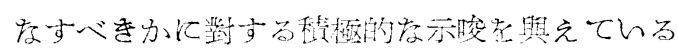

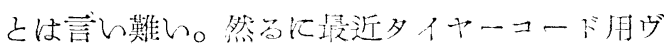

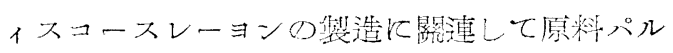
プ或はレーヨン肖體の分子量你有が，レーヨン

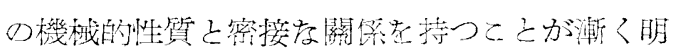

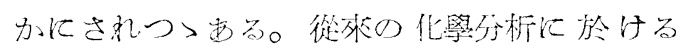

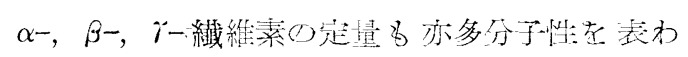
す一つの尺度で恃るが，原料瀻維素分子の多 分散性，或的红重合度分有老多つ之精細化考察

\section{することが重要に学つて來た。}

\section{レーヨンの機㳦的性誓上電合度分布上の關係}

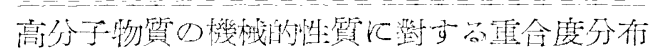

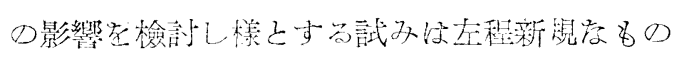

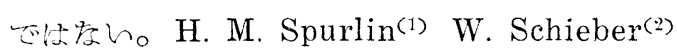

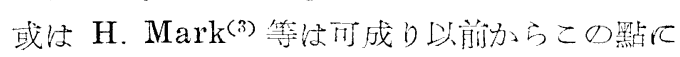

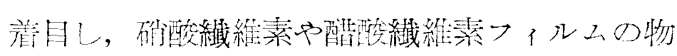

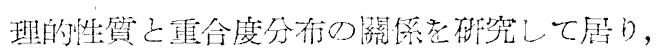

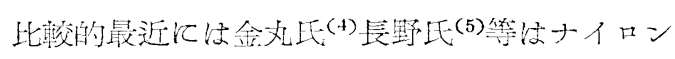
繊維及びポリヴィニルアルコール皮膜等汇關守

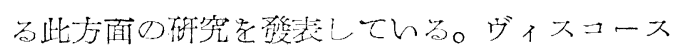
瀻維以外の高分子物筫老敢报つ庆乙礼等の多く

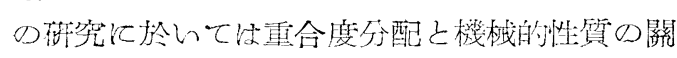

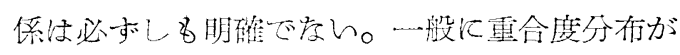

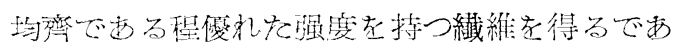

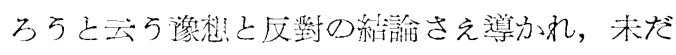

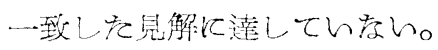

然るに最近朵ィスコース瀻維に關して䋁表さ れを㪷究老見ると，他の高分子化合物の場合之 事情が異度り，分子量分行とレー寻ンの機柀的

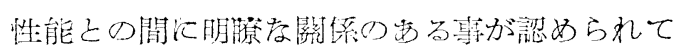
居る。特化タイヤーコードの疲熒强度とパルプ 或はレーヨンの重合度分有（或恃低分了物の念

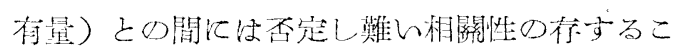
之が指摘されている。(6)(7)(8)餘談化涉るが，昨 夏箱者 (㻕尾) が渡米してアメリカンヴィス

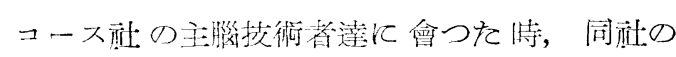

